\title{
The Phenomenon of Creative Economy in Ukraine and Defining Its Place in the Architectural Space
}

\author{
Kateryna Holubchak* \\ Department of Architecture and Urban \\ Planning \\ Ivano-Frankivsk National Technical \\ University of Oil and Gas \\ Ivano-Frankivsk, Ukraine \\ http://orcid.org/0000-0001-5043-0496
}

\author{
Yuriy Chuchuk \\ Department of Accounting and \\ Taxation \\ Ivano-Frankivsk National Technical \\ University of Oil and Gas \\ Ivano-Frankivsk, Ukraine \\ yuriy.chuchuk@gmail.com \\ Inna Negrych \\ Department of Accounting and \\ Taxation \\ Ivano-Frankivsk National Technical \\ University of Oil and Gas \\ Ivano-Frankivsk, Ukraine \\ merina@bigmir.net
}

\author{
Tetiana Savchuk \\ Department of Accounting and \\ Taxation \\ Ivano-Frankivsk National Technical \\ University of Oil and Gas \\ Ivano-Frankivsk, Ukraine \\ https://orcid.org/0000-0001-9742-9046
}

\begin{abstract}
The article shows the strong and weak sides of the current situation in the area of creative economy in Ukraine as well as develops the list of proposals for supporting and activating its potential. The innovative approach and research significance is presented at the intersection of economy and architecture in as much as the study also sheds light on the typology and architectural functional issues of innovative creative spaces and structures, which are the centers of creative economy flourishing. The authors' research material includes analysis of existing creative spaces of Ukrainian cities as well as gives architectural proposals of future creative hub designed by author's supervision.
\end{abstract}

Keywords-creative economy, creativity, creative spaces, hubs, architectural organization, design concept.

\section{INTRODUCTION}

Modern functioning of the world economic system is characterized by a new stage of economic development, the basis of which is the dominance of knowledge and creativity, intellectual labor, innovations. With the rise of creative economy and informational technologies over the past two decades, the need for people to communicate, collaborate, cocreate, inspire and learn from each other became increasingly important, as well as the need in proper architectural and design strategies of spaces providing these opportunities might be more relevant than ever before. This is proved by the rapid rise of the number of creative spaces across the globe. However, profound knowledge and academic research on the influence of creative economy and innovations on design and architecture of such spaces are still limited. Current research fills that gap by investigating the number of socio-economic, technological and design factors for designing innovative creative spaces that are called to facilitate flourishing and development of creative economy in Ukraine. Thus the main purposes of the study are: to analyze the concept of creativity, creative class and creative industries in Ukraine as well as the current state of national creative economy; to highlight the term of creative environments and architectural peculiarities of creative spaces which form the main elements of creative cities; to identify the opportunities of transforming Ukraine into prosperous creative economy country.

\section{LITERATURE OVER VIEW}

Various aspects connected to the theoretical and practical peculiarities of creative industries and creative economy were fundamentally investigated by different scientists in the last few years. R. Florida, J. Howkins, H. Antti, G. Kharlamova, O. Gumenna and many others presented their views on creative economy through the prisms of various fields of science - economy and entrepreneurship, marketing, tourism, architecture and design, art and urban studies. Prospects for the development of creative economy in Ukraine were explored by I. Skavronska, Yu. Ushkarenko, V. Chmut, A. Syniakova, L. Fedulova and others.

John Howkins, the scientist who introduced the concept of creative economy, depicts creativity as a "process of using ideas to produce a new idea (...) in the sense of giving a new meaning to somenthing". The realisation of these ideas leads to production which generates high added value and marked economic growth [1]. He finds the roots of creative economy in the knowledge economy. Ukrainian scientists consider the creative economy, the knowledge economy and the innovation economy to be the components of each other, and "each of them is part of the concept of a new economy, which can be interpreted as a high-tech economy, which requires the subjects of continuous innovation in the context of globalization" [2]. Hautamäki Antti in his research investigates creative economy and culture as the key point of innovation policy. He comes to conclusion that innovations flourish in special interactive environments, called 'innovation ecosystems, which include a number of factors providing a good soil for idea generation and their realization in the form of products, services and new paradigms"[3].

A number of studies investigates the concepts of creative cities and creative clusters. The concept of the "creative city" 
was developed and described by urbanist Charles Landry [4]. He considers creativity as a key factor that allows modern city to respond modern challenges and to provide technological innovations and rediscover their cultural heritage. The creative city is an urban complex where "various kinds of cultural activities become an integral part of the city's economic and social life, and include intellectual capital applied to products, processes and services" [5]

According to Landry creative cities have caused the emergence of the new social category and driving force for economic development - the creative class. Richard Florida [6], the first who proposed the concept of creative class, defines it as a group of creative workers in science, arts, education, engineering, architecture, design, music and other cultural and creative industries, whose economic function is to create new ideas, innovations and creative content.

Statistics and official reports by the British Council, UNESCO [7], The World Bank Group [8], The Report on a coherent EU policy for cultural and creative industries [9] and others are of particular importance for this study.

The official report by United Nations "Creative Economy Outlook Trends in international trade in creative industries" [10] gives a detailed outlook on the global creative economy and illustrates the main trends in the world trade of creative services and goods for the period 2002 to 2015, which allows to see the amazing dynamics in the development of creative economy. The report gives information on creative economies for 130 country profiles and highlights the main opportunities for potential development in these countries "to increase their production, exports and share in creative industries markets" [10].

The official report by the British Council "Creative Hubs: Understanding the New Economy" [11] aims to better understanding the diverse value, processes and motivations of creative spaces and includes deep analyses on the ways supporting and stimulating the wider creative economy they are rooted in [11]. The report reveals that creative hubs are lighthouses for abandoned city areas which form communities, gather people inspiring them for new cross disciplinary collaborations and modes of working. Although the publication is focused on creative hubs in the UK, the principles revealed can be relevant everywhere.

The official report of The World Bank Group on creative community spaces [8] showcases a selection of physical spaces around the world that enable innovation and contribute to building a creative community that is sustainable and entrepreneurial. These spaces include incubators, coworking spaces, accelerators, fab labs and hacker spaces. This report aims to facilitate a conversation about the strong role of creative spaces in the development of urban ecosystem [8].

The publication "Creative HubKit" prepared by the British Council illustrates some of the positive experiences and approaches to building sustainable creative hubs and gives practical advice and tools to build a successful creative hub with a strong community and structure [12].

The number of existing studies focused namely on specifics and factors of creative economy, the general concepts about creative cities and clusters without touching methods of its architectural expression, show that there is a lack of knowledge on architecture and design aspects in relation to socio-spatial, functional questions of creative spaces. Filling the gap, this study aims to find important factors and design aspects that lead to the creation of a successful creative space, which facilitates collaborative learning, social networking and serendipitous crossfertilization of innovative ideas and skills.

\section{RESULTS OF THE STUDY}

\section{A. Creative economy in Ukraine. Challenges and opportunities.}

The creative economy aims to create an attractive investment climate, increase the competitiveness of regions, promote the development of the social sphere, modernize the education sector and so on [13]. Within the creative economy, new economic models, new types of social relations, and new cultural paradigms are emerging, as well as a new value, communication and instrumental sphere, in which consumption of goods and services recedes into the background, and the creation of opportunities for creative expression and self-realization of each person comes first. Creative economy influences the image of cities, and also stimulates the urban community to the new, better life, to the interpenetration of different spheres of thinking and employment. Thus, cities are becoming a huge space for communication, new ideas, and economic growth.

The main components of the creative economy are creative industries based on creativity. In the context of globalization, creativity has become a powerful source of competitive advantage and a driving force for progress. Ukrainian scientist I. Skavronska describes creativity as 'an inexhaustible resource based mainly on the ideas and cultural characteristics rather than on the physical capital'. The main source of creativity is invisible as it includes talent, personal emotions, knowledge, intuition, imagination, the ability to produce new ideas, and to solve problems - and cultural assets of each society (traditions, cultural values and heritage) [14]. Talented Ukrainian people possess a huge creative potential, which is forced with valuable national historic and cultural heritage. Being rich in cultural traditions and history, Ukraine is presented as the preserver of national identity, as well as the custodian of unique creative ideas generated by the talented Ukrainian people, which provides the country with powerful cultural foundations for potential economic growth.

The assessment of creativity in Ukraine is of great importance for current study. The lack of official reports and statistical data for Ukraine substantially limits further research in this area, though we need to take into consideration the official reports by famous world organizations, which studied in detail the state of the creative economy and the development of creative industries around the world.

According to the Global Creativity Index (GCI), calculated by the Martin Prosperity Institute [15], Ukraine ranks the 45th place among 139 countries. The Global Creativity Index measures countries by three key indicators of economic development - technology, talent and tolerance. In particular, the rating takes into account investments in research and development, the number of researchers and patents, the level of education, and data from sociological 
surveys. The huge difference between the talent index and the technology index (respectively, 24 and 43 place) indicates that the level of new developments in Ukraine is much lower than the number of people who can potentially implement these developments.

The similar result for Ukraine can be seen in Global Innovation Index report, developed by Cornell University, INSEAD, and the WIPO, according to which Ukraine ranks the 47th place among 129 countries. It proves the fact that creativity and innovation are two interdependent concepts. The 2019 Global Innovation Index report [16] provides information on the innovative activities taking into account 80 parameters that give a complete picture of innovative development, including an overview of the political situation, the state of education, the level of infrastructure and business. At the request of the Kyiv Smart City Initiative, the analytical center CEDOS [17] has developed a methodology for measuring the Index of Cultural and Creative Capacity of Ukrainian Cities (figure 1).

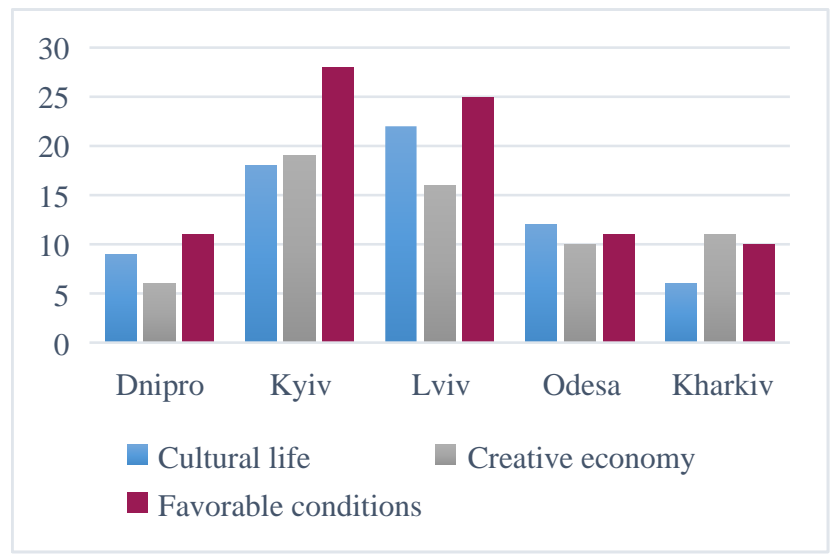

Fig. 1. Index of Cultural and Creative Potential of Ukrainian Cities. (compiled by author, based on sourse [17])

Within the framework of the approbation research project "Index of Cultural and Creative Potential of Ukrainian Cities", analysts have developed a methodology for determining the urban creativity index by more than one hundred indicators. The survey covered five major cities: Dnipro, Kiev, L'viv, Odessa and Kharkov. The indicators used to measure the Urban Cultural and Creative Capacity Index are grouped into three sub-indices: cultural life; creative economy; creating conditions conducive to the development of culture and creativity (figure 1).

The leading role of Creative Industries in national economic growth is provided with their dynamic nature, enormous contribution to production and employment, and huge potential for growth. In can be illustrated in the report on a coherent EU policy for cultural and creative industries [9], according to which by Europe, Creative Industries provide more than 12 million full-time jobs in Europe, which amounts to $7.5 \%$ of the European work-force, creating approximately $€ 509$ billion in value added to Gross Domestic Product (GDP). The report illustrates that the highest contribution of the creative industries to GDP is in the USA $-11.2 \%$ and the highest contribution of the creative sector to employment is in Netherlands - $8.8 \%$. Unfortunately, Ukraine's economy poorly supports the creative initiatives and shows rather low results in comparison to Europe, North America or Australia - the input of the creative industries to GDP is only $3.47 \%$, and the contribution to employment equals $1.91 \%$ [14].

The data above illustrate that Ukraine ranks rather modest position in the development of creative economy, though it should be mentioned that such position doesn't indicates low potential for developing it. On the contrary such potential exists, and can be improved by creating smart strategy for enhancing creative industries and the human capital, by formation of creative infrastructure and rational network of creative spaces throughout the country and finally improving legal framework concerning intellectual property and skills for business.

The report "Developing Cultural and Creative industries in Ukraine" [18] developed with the assistance of the EUEastern Partnership Culture and Creativity Programme, analyses the current state of creative industries in Ukraine, identifies their challenges and opportunities (figure 4), and finally draws recommendations and further steps to be done.

TABLE I. CREATIVE ECONOMY IN UKRAINE. CHALLENGES AND OPPORTUNITIES

\begin{tabular}{|c|c|}
\hline Opportunities & Challenges \\
\hline $\begin{array}{l}\text { Decentralization creates an } \\
\text { opportunity for governments to } \\
\text { invest into creative sectors. }\end{array}$ & $\begin{array}{l}\text { Creative industries are not } \\
\text { recognized as priority field for the } \\
\text { country's overall development. }\end{array}$ \\
\hline $\begin{array}{l}\text { Emergence of platforms that } \\
\text { promote creative industries. }\end{array}$ & $\begin{array}{l}\text { Low cooperation of central and } \\
\text { local authorities in cultural area }\end{array}$ \\
\hline $\begin{array}{l}\text { Tendency of emerging creative } \\
\text { spaces throughout the country }\end{array}$ & $\begin{array}{l}\text { Lack of support and proper } \\
\text { business models for emerging } \\
\text { creative institutions }\end{array}$ \\
\hline $\begin{array}{l}\text { Recent establishment of the } \\
\text { competitive funding system - } \\
\text { Ukrainian Cultural Fund }\end{array}$ & $\begin{array}{l}\text { Week legal framework for } \\
\text { creative business promotion, low } \\
\text { attractiveness for investments. }\end{array}$ \\
\hline \begin{tabular}{lrr} 
Development & of & new \\
fundraising & initiatives & to \\
supporting & \multicolumn{2}{c}{ creative } \\
entrepreneurship & &
\end{tabular} & $\begin{array}{l}\text { Low development of alternative } \\
\text { funding sources and specialized } \\
\text { support services for creative } \\
\text { entrepreneurs. }\end{array}$ \\
\hline $\begin{array}{l}\text { Establishment of open } \\
\text { platforms for informal learning } \\
\text { and creative skills development } \\
\text { as well as relevant curricula } \\
\text { offered by higher education }\end{array}$ & $\begin{array}{l}\text { Low promotion of creativity and } \\
\text { entrepreneurship in education and } \\
\text { training programs. }\end{array}$ \\
\hline $\begin{array}{l}\text { Popularization of "Made in } \\
\text { UA" movement, Ukrainian } \\
\text { festivals, selling opportunities } \\
\text { for UA brands. }\end{array}$ & $\begin{array}{l}\text { Lack of knowledge on the } \\
\text { legislation of certification of } \\
\text { national creative products }\end{array}$ \\
\hline $\begin{array}{l}\text { Promotion of Ukraine on } \\
\text { international stage. Joining the } \\
\text { Creative Europe Program }\end{array}$ & $\begin{array}{l}\text { Low international mobility } \\
\text { support, no skills for international } \\
\text { networking which prevents long- } \\
\text { term international partnerships. }\end{array}$ \\
\hline
\end{tabular}

B. Creative spaces as the main condition for flourishing of the creative economy. Architectural and design aspects of creative economy.

New knowledge and creative skills which lead to disruptive innovation and are the most powerful drivers of 
economic growth in the modern economy, are formed at the intersection of fields and cultures. Over the past few years, more and more innovation spaces, ideation hubs, incubator labs and coworking spaces were designed to inspire people from diverse cultures and fields of expertise to interact with each other and foster creativity. The first who recognized the significance of such spaces were global companies like Google, Tweeter and Facebook which provided their offices and campuses with inspiring creative infrastructure for their employee. And only recently governmental structures at all levels, industry corporations, educational establishments and research institutions have started providing similar environments for the general public. [19]

Modern creative environment is rich in different innovative forms of entrepreneurship like clusters, hubs, coworkings, business-incubators, accelerators, which became the strengthening power for regional competitiveness and economic growth. Thus, idea generation needs a combination of skills, knowledge, talented individuals, and above all a good inspiring creative environment. These new forms of creative spaces should be designed properly with deep understanding of the specifics of the processes that will take place there and taking into account the latest architectural and design trends in order to fully realize their functions.

The main task of architects and designers when designing buildings is creating special environment that promotes emotions, activities and practices, typical to the vision and function of the space. Modern architecture is defined not only by some geometrical forms and dimensions, but first of all by emotional context. Similarly, like the architecture of churches and religious centers inspire people for spiritual practices and praying, offices are designed for stimulating efficient work, in the same way creative hubs should promote idea generation, innovative thinking and collaboration. The emergence of the latest design and digital technologies has greatly expanded the design space of architecture. The spatial structure of modern creative hubs cannot be formed only by physical material, but it should have a wide range of digital and light components embedded, as well as new constructive elements like transformative partitions, modular furniture, that can easily adopt every space to certain needs - from private working zones to group coworking spaces. In this context, the architecture of creative spaces promotes "accommodation, separation, organizing, structuring, facilitation and even celebrating human spatial behavior" [19].

The next point which should be taken into account when designing creative environment is the target audience. Different social communities might have various spatial requirements and motivations, which must be illustrated in architectural decisions.

The wide range of functions performed by innovative creative spaces causes need for their proper classification according to the predominant function. Regardless of the space occupied and location in an urban environment, in all creative spaces there is a certain functional structure, which is formed on the basis of main functions - business, educational, entertaining and complemented by the functions of catering, exhibitions and others. Creative spaces can be monofunctional with prevailing certain function, but most part of creative spaces are based on two or more functions.
All creative spaces, depending on the predominance of a particular function can belong to the following types: the business function is represented by such creative spaces, as coworking, educational function - lectoriums, new-type classrooms and educational hubs.

One of the most powerful guarantees for the flourishing of the creative economy in Ukraine is the formation of a proper infrastructure and a well-developed network of creative spaces which are aimed at improving the communicative and creative abilities of a person and play a great role in developing business with a creative beginning. Creative spaces produce a great impact on the city's image, attractiveness and its economy. Creative Hubs produce a wide range of positive impacts - from fostering talents and start-ups, creating new products and innovative services, to providing good educational opportunities. Creative Hubs are shaped by the needs and demands of local creative industries and 'are embedded in particular cultural contexts, supporting specialized creative practices and developing their own value systems' [12].

Currently, a good network of creative spaces, which are represented in their wide typology - from small coworkings and business incubators to huge creative hubs are functioning successfully on the territory of Ukraine. In a short period of time they gained popularity and thoroughly introduced into urban life, their number is growing steadily every year. There are many good examples of successful projects realized in Ukraine, including: Creative Quarter (Kyiv), Jam Factory Art Center (L'viv), Innovative center "Promprylad. Rennovation" (Ivano-Frankivsk), Art-factory "Platforma" (Kyiv), iHUB - network of centers for innovation and entrepreneurship in IT-sphere (all over Ukraine). These are the most famous examples of creative spaces. Especially developed network of creative centers is observed in major cities of the country, the leader is definitely the capital. As of the beginning of 2019, Kyiv has 106 creative hubs of different types. However, not all of them are designed properly and therefore do not provide full implementation of their functions. Special focus should be made on their architectural-spatial and functional arrangements.

These data demonstrate the relevance of the study both the phenomenon of creative space, and analysis of the typology of creative spaces and the foundations of their architectural and planning organization.

Formation of creative spaces is also a priority of the Government of Ukraine - in Strategy "Ukraine - 2030. The Doctrine of Sustainable Development" [20], namely through the development of the creative cluster, it is planned to implement positive dynamics in the formation of human capital, economic development and improvement of the quality of the urban environment. Another positive movement in this area was the adoption of the Strategy of development of the sphere of innovative activity for the period till 2030, approved by the Cabinet of Ministers, on July 10, 2019 [21]. The document, in particular, provides the development of innovative infrastructure, the creation of a favorable legal framework for innovation, the provision of new mechanisms for the transformation of creative ideas into innovative products and services and more. This position, together with the emergence of increasingly new forms of creative spaces, raises the question of exploring creative 
spaces in an urban-planning context - where and how they are most often formed, how they interact with existing buildings and the functions of the environment.

As for the location of creative hubs in the structure of the city, there are no clear restrictions. In most cases, these establishments are located in the city center, due to the mutual benefit of owners and visitors. Creative spaces can make important contribution to the development community, creative business and urban renovation. Creative hubs are able to revitalize undeveloped city quarters. It is a perfect investment to bring a new life to abandoned or non-used industrial spaces, buildings and venues.

In this context it should be mentioned about the popular trend - reconstruction, which has a number of significant advantages compared to the construction of a new building. First of all, it is the financial side, which allows the investor to save money. Another important factor is the architectural component, since it brings non-used parts of cities back to life and contributes to urban development. The range of such structures is very wide - from non-functioning plants to buildings with a certain historical value. These are places for learning and working, sharing knowledge, meeting, and interacting. The aim of the development of creative spaces in the urban environment is providing creative young people (creative class) with new opportunities for learning, skills exchange, experimentation and implementation of their own vision of the city and world and in such a way to unite the creative potential of the city promoting its regional development.

For example, the Innovation Center "Promprylad. Renovation" (Ivano-Frankivsk, Ukraine) created at the base of the former plant gives a wide range of new opportunities in four different sectors - art, education, new economy, and urbanistic (figure 2). The first reconstruction phase of the building was started in 2017 and finished in 2018. The renovated third floor $\left(1783 \mathrm{~m}^{2}\right)$ of the project includes a wide range of amenities (coworking zone, space for workshops, laboratories, educational and children's attractions, conference room, art gallery, bar, offices of innovative organizations [20].
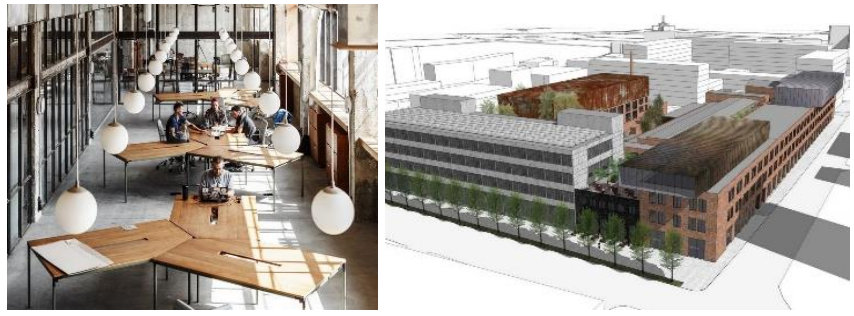

Fig. 2. Innovation centre "Promprylad. Renovation". (interior and exterior (vizualisation)). Sourse [17]

The rest parts of the former plant $\left(36650 \mathrm{~m}^{2}\right)$ are expected to be renovated and adopted to new functions during the next few years. Due to the crowd investing model, which is used for this aim, the Ukrainian businesses, international investors and the local community will have an opportunity to purchase Promprylad. Renovation shares and become part of the project and its goals. [22]. The project is an example of impact investing and opened to partnerships. Investors invest in social initiatives, become co-owners of the plant and receive dividends
Being a powerful creative platform for collaboration between community, business and local government the project is expected to produce a great impact on local and regional development. Therefore, this positive experience may become a successful model for implementation in other territories in Ukraine with unfavorable starting conditions.

Another points which should be taken into account are developing the educational facilities which promote the development of creativity and innovations, and formation of strong financial background for investment possibilities into research, science fields and educational sector. Creating strong links among universities, creative enterprises and business plays a catalytic role in the development of creative economy. Thus the formation of creative hubs in the structure of universities which become magnets attracting innovation and creative activity is one of the first steps to be done. Moreover, essential creative skills, innovative thinking and participation in wide range of creative practices should be integrated into the courses and curricula of educational and training establishments at all levels from schools to universities.

In Ukraine some positive movements can be seen in this area, a great amount of educational institutions are starting to include some creative activities and creative economy courses in their curricula. For example, due to The Creative Spark program, funded by The British Council, IvanoFrankivsk National Technical University of Oil and Gas started providing a number of trainings on creative entrepreneurship for students and young entrepreneurs. It is a good starting point in creating a positive ecosystem for preparing professionals for the creative industry.

During the fall semester, students of the Faculty of Architecture were involved in the design of a creative hub based on a former dining room at IFNTUOG (Figure 3 ).

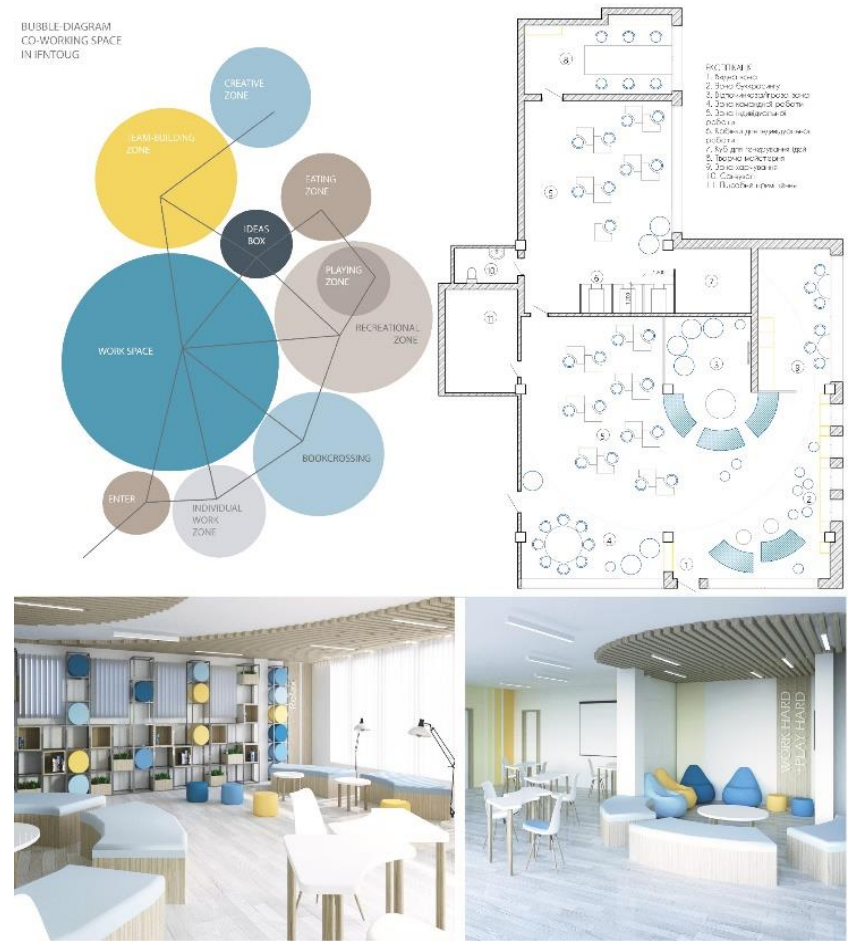

Fig. 3. Creative Hub in IFNTUOG. (Students' project, designed under author's supervision (K. Holubchak)) 
The experiment showed positive results, because the architectural and spatial solution has covered all aspirations and visions of potential users. In the process of working on the project, students conducted a large-scale sociological study, which revealed the potential needs and wishes of students and teachers to the architectural organization of the hub environment.

The aim of the project is to provide a multifunctional coworking space for a wide range of creative initiatives and social learning which forms as a result of students' collaboration, sharing and communication in the same workspace. With these objectives it has been architecturally designed in an open and accessible way. Few several distinct spaces (conference zone, coworking, spaces for individual work, idea-generation cube and others), with no separation between them form one creative environment, where students communicate, inspire each other, working side by side and produce innovations. Now the project is in the initial stage of implementation.

\section{CONCLUSIONS}

Thus, today the creative economy is a strong strategy for social development, based on continuous human-based innovations, provided by intellectual capital, creative potential and talent. In the context of European integration, the development of creative industries can provide enhancement competitiveness of the Ukrainian economy and ensure a long-term economic growth.

Ukrainians and especially young people have a huge creative potential which needs to be managed in a proper and competent way. According to the research we can formulate a number of recommendations on developing creative economy sector in Ukraine: raising importance of creative economy and value of creativity among society at all governance levels; developing sustainable action plan as well as preserving and promoting the historical, spiritual and cultural values; formation of favourable ecosystem and business conditions for creative start-ups as well as legal framework for creative business; establishment of necessary infrastructure and creative hubs for encouragement of the Ukrainian creative people, support and motivate them to develop their talent in their home regions; promotion of creativity as well as entrepreneurial skills throughout education system among wider audiences; providing international cooperation and trade for spreading Ukrainian talent and creativity and brand worldwide; improvement of national statistics for futher analysis and prognosis in this area.

The current research shows that creative spaces, which have been dynamically appearing throughout the country in the last few years, are able to produce a huge range of positive impacts, like new jobs creation, innovative products, services and level of education, supporting talented people, urban regeneration and promotion of Ukraine on international level.

\section{REFERENCES}

[1] J. Howkins, The Creative Economy. How People Make Money from Ideas. London, UK: Penguin Books, 2013.
[2] Iu.V. Ushkarenko, A.V. Chmut, and K.M. Syniakova, "Creative Economy: The Essence of The Concept and The Significance for Ukraine Under The European Integration", Economy and Society. vol.18, pp. 67-72, 2018 [in Ukrainian]

[3] A. Hautamaki, Creative economy and culture at the heart of innovation policy. Helsinki, Finland: Helsinki University Print, 2010

[4] C. Landry, The Creative City: A Toolkit for Urban Innovators, 2nd Edition. London, UK: Earthscan, 2012.

[5] K. Petrikova, A. Vanova, and K. Borsekova, "The role of creative economy in Slovak Republic", $A I$ \& $S o c$, vol. 30, no. 2, pp. 271-281, 2015.

[6] R. Florida, The Rise of the Creative Class. 2nd ed. New York, USA: Basic Books, 2012.

[7] Unesco. (2016) "Creative Industries. United Nations Educational, Scientific and Cultural Organization". [Online]. Available: http://www.unesco.org/new/en/santiago/culture/creative-industries/. Accessed on: July 18, 2019.

[8] V. Mulas, A. Nedayvoda, and G. Zaatari, Creative community spaces: spaces that are transforming cities into innovation hubs. Washington, D.C, USA: World Bank Group, 2017.

[9] European Parliament (2016). Report on a coherent EU policy for cultural and creative industries. [Online]. Available: http://www.europarl.europa.eu/doceo/document/A-8-20160357_EN.html

[10] UNCTAD. (2015). Creative Economy Outlook and Country Profiles: Trends in international trade in creative industries, [Online]. Available: http://unctad.org/en/pages/newsdetails.aspx.

[11] T. Virani, J. Dovey, A.T. Pratt, J.L. Lansdowne, S. Moreton, and J. Merkel, Creative Hubs: Understanding the New Economy. London, UK: City University of London, 2016.

[12] J. Matheson, and G. Easson, Creative Hub Toolkit. London, UK: British Council, 2015

[13] S. A. Davymuka, and L.I. Fedulova, Creative economy sector: experience and directions of development, Lviv, Ukraine: Dolishniy Institute of Regional Research of NAS of Ukraine, 2017 [in Ukrainian].

[14] I. V. Skavronska, "Creative Industries in Ukraine: Analysis and Prospects of the Development", Economics and Sociology, Vol. 10, No. 2, pp. 87-106, 2017

[15] R. Florida, C. Mellander, and K. King, Global Creativity Index 2015, Toronto, Canada: Martin Prosperity Institute, 2015. [Online]. Available: http://martinprosperity.org/media/Global-Cre ativityIndex-2015.pdf. Accessed on: July 19, 2019

[16] Cornell University, INSEAD, and WIPO. (2019). Global Innovation Index Report 2019, [Online]. Available: www.globalinnovationindex.org/. Fontainebleau, Ithaca, and Geneva. Accessed on: July 21, 2019.

[17] Index of Cultural and Creative Potential of Ukrainian Cities, 2019. [Online]. Available: https://cedos.org.ua/uk/articles/ dosvidvymiriuvannia-kultury-ta-kreatyvnosti-v-mistakh-ukrainy. Accessed on: July 15,2019

[18] C. Farinha, Developing Cultural and Creative industries in Ukraine, London, UK: British Council, 2017.

[19] M. V. Bilandzic, "The embodied hybrid space: designing social and digital interventions to facilitate connected learning in coworking spaces", Ph.D. diss., Queensland Univ. of Technology, Brisbane, Australia, 2013

[20] Ukraine 2030. The Doctrine of Sustainable Development, 2019. [Online]. Available: http://www.usubc.org/files/Ukraine_Doctrine_2030_E_Book_Eng.pd f. Accessed on: July 17, 2019.

[21] The Strategy of development of the sphere of innovative activity for the period till 2030, 2019. [Online]. Available: https://zakon.rada.gov.ua/laws/show/526-2019-\%D1\%80?lang=uk. [in Ukrainian]. Accessed on: July 17, 2019.

[22] Promprylad. Renovation, 2019. [Online]. Available: https://warm.if.ua/projects/promprylad. Accessed on: July 17, 2019. 